\title{
Aluminum-Magnesium Silicate enhances release of virions of cultured Fowl Pox Virus and inhibits the virus
}

\author{
Maduike C. O. Ezeibe*, Emmanuel Ekeanyanwu, Augustine A. Ngene, ljeoma J. Mbuko \\ Department of Veterinary Medicine, University of Nigeria, Nsukka, Nigeria; *Corresponding Author: maduikeezeibe@yahoo.com
}

Received 1 June 2013; revised 3 July 2013; accepted 26 July 2013

Copyright (C) 2013 Maduike C. O. Ezeibe et al. This is an open access article distributed under the Creative Commons Attribution License, which permits unrestricted use, distribution, and reproduction in any medium, provided the original work is properly cited.

\begin{abstract}
Antiviral effects of a synthetic Aluminum-Magnesium Silicate (AMS) were tested on Fowl Pox Virus (FPV). Five batches of the Nigerian brand of FPV vaccine were used as sources of the virus. The reconstituted vaccines were mixed with The Synthetic AMS on equal volume to weight basis and incubated at room temperature for one hour. They were centrifuged for 10 minutes at 2000 revolutions per minute. The incubation and centrifugation were repeated on a portion of each vaccine supernatant. The two sets of supernatants were tested by the Modified Passive Haemagglutination test, for FPV titres. Portions of the vaccines, not incubated with the AMS, were served as controls. Fowl Pox Virus titres of the vaccines increased from a mean of $2.8 \pm 1.10$ to $11.2 \pm 4.38$ when incubated with the AMS once. When incubation with the AMS was repeated, the titres reduced $(P<0.05)$ to zero in each sample.
\end{abstract}

Keywords: Aluminum-Magnesium

Silicate-Nanoparticles; Antiviral Effects;

Anticancer Potentials; Fowl Pox Virus

\section{INTRODUCTION}

Fowl Pox Virus belongs to the Avipoxviridae viral family [1]. The disease it causes is a major cause of economic losses in poultry, because it results in drop in egg production, weight loss and poor carcass quality due to the lesions it causes on dressed chicken.

Pox disease in chicks manifests in two forms. Cutaneous pox occurs on the unfeathered parts of affected birds' bodies (heads, combs and wattles), while the diphtheritic form leads to lesions (canker) in mucous membranes of the mouth, larynx and trachea [2]. The diphtheritic le- sions in the trachea are often confused with lesions of avian herpesvirus or lesions of Infectious laryngotracheitis [3].

Avipoxviruses are among the largest and most complex animal viruses and have worldwide distribution. Pox disease has been reported to affect over 232 species in 23 orders of birds, including chickens, turkeys and pigeons [4].

In chickens, fowl pox affects all ages, all sexes and all breeds. There is at present no treatment for the disease. Antibiotics are used just to control secondary bacterial infections and vitamin A helps to heal the lesions [5].

Aluminum-Magnesium Silicate (AMS) is safe for use on food animals [6]. Vanderbilt [7] also reported that AMS is used to bind drugs into tablets which are used in treating humans and animals. So, the chemical is safe for use in animals and humans, as medicine.

Molecules of AMS have negative electrical charges on their surfaces and the positive charges on their edges [8]. Since viruses also have electrical charges [9], if AMS is used as medicine, extracellular viruses may adsorb onto it and thus fail to attach to host cells. This would inhibit infection at the stage of attachment of the virus to host cells.

The Synthetic AMS got from reaction of Aluminum silicate and Magnesium silicate [10] has exhibited antiviral effects against all four viral families, so far tested, including, Paramyxoviridae, Birnaviridae, Parvoviridae and Othomyxoviridae [10]. A need therefore exists to test it against other viral families.

\section{MATERIALS AND METHODS}

Five batches of fowl pox vaccine (National Veterinary Research Institute, Vom, Nigeria) were each reconstituted with PBS, at the rate of $5 \mathrm{ml}$ for each 200 doses. Four $\mathrm{ml}$ of each of the reconstituted vaccines was mixed with equal volume (4 g) of The Synthetic AMS [10] and kept 
at room temperature for one hour. The mixtures were then centrifuged for 10 minutes, at 2000 revolutions per minute. The incubation of Fowl Pox Virus with AMS was repeated by mixing a volume of supernatants of the vaccines (2 ml) with equal amount of the AMS (2 g). The mixtures were again incubated at room temperature and centrifuged.

Modified passive haemagglutination test (MPHA) already described [11] was used to test the vaccine supernatants, for virus titres. Portions of the vaccines which were not incubated with the AMS served as controls. Mean titre of FPV in the portions of the vaccines not incubated with the AMS (controls) and means of the virus in the vaccines after the first and the second incubations, were tested for statistical differences, by Analysis of variance.

\section{RESULTS}

Incubating fowl pox vaccines with Aluminum-Magnesium Silicate significantly $(\mathrm{P}<0.05)$ increased viral titres of the vaccines from a mean of $2.8 \pm 1.10$ to $11.2 \pm$ 4.38 but when incubation with the AMS was repeated, viral titres of all the vaccine batches reduced $(\mathrm{P}<0.05)$ to zero (Table 1).

\section{DISCUSSION}

Fowl pox disease is one of the greatest challenges facing the poultry industry, especially in developing countries. This is mainly due to poor biosecurity measures available in those countries. Like most other viral diseases, it has no treatment. It is therefore important to search for antiviral agents that can inhibit the virus and cure infected chicks or prevent spread of infection in infected flocks.

In replication cycle of Fowl Pox Virus, after the viral

Table 1. Modified Passive Haemagglutination titres of Fowl Pox Virus in the vaccines, incubated with The Synthetic AluminumMagnesium Silicate.

\begin{tabular}{|c|c|c|c|c|}
\hline & $\begin{array}{l}\text { Number of } \\
\text { incubations }\end{array}$ & 0 & 1 & 2 \\
\hline \multicolumn{5}{|l|}{$\begin{array}{l}\text { Vaccine } \\
\text { samples }\end{array}$} \\
\hline 1 & & 4 & 16 & zero \\
\hline 2 & & 2 & 8 & zero \\
\hline 3 & & 2 & 8 & zero \\
\hline 4 & & 4 & 8 & zero \\
\hline 5 & & 2 & 16 & zero \\
\hline Mean titres & & $2.8 \pm 1.10$ & $11.2 \pm 4.38$ & zero \\
\hline
\end{tabular}

Incubating cultured Fowl Pox Virus with The Synthetic AMS increased (P < 0.05 ) their titre initially but a repeat incubation with the chemical reduced ( $\mathrm{P}$ $<0.05$ ) the titre. materials have assembled, the new virions get released by two methods. Some virions bud off the host cells completely while others remain attached on surfaces of the cells [5]. Viruses that remain attached to host cells would not be able to sensitize (infect) RBCs and so would not produce passive agglutination of the RBCs. So, their presence would not be detected by the passive haemagglutination test. AMS has been reported to assist in disintergrating capsules within gastrointestinal tract of treated patients [7]. It is therefore possible that the first incubation with the AMS leads to disintegration of the cells used to culture the Fowl Pox Virus in the process of vaccine production, and so, releases virions that are still attached to surfaces of the cells. Fowl Pox Viruses, released from the cells, may have sensitized the sheep RBCs at higher dilutions of the vaccine supernatants, thus leading to the significant increase of viral titres of the vaccines, from $2.8 \pm 1.10$ to $11.8 \pm 4.38$.

The observation that when samples of some viruses are incubated with The Synthetic AMS, their viral titres increase instead of reducing was also made [12] when it was used to incubate vaccines of Peste des Petits Ruminants Virus (PPRV). PPRV is one of the morbilliviruses which have close association with cells [13] as FPV does. Molecules of Aluminum-Magnesium Silicate are composed of platelets that are only $0.96 \mathrm{~nm}$ thick [7]. So, AMS is made of Nanoparticles [14] which have been reported to selectively deliver drugs to cancer cells [15]. The Synthetic AMS used in this study has been used for in vivo treatment of chicks, dogs, mice and rats [16-23] without adverse side effects on treated animals. That suggests that it is safe to healthy cells. So, its ability to disintegrate cells infected with PPRV and those infected with FPV to release associating virions suggests that it may also have the ability to act selectively on abnormal cells. So, it may be among the Nanoparticles which have anticancer potentials. Its affinity for infected cells would also aid its antiviral effects, as it would disintegrate infected cells and thereafter, adsorb virions released from the cells.

The zero titre got following a repeat incubation of the vaccines with the AMS suggests that AMS was able to inhibit FPV completely. This result agrees with earlier results got with use of the AMS on Peste des Petits $\mathrm{Ru}$ minants Virus [24], Infectious Bursa Disease virus [16], Canine parvovirus [17], Egg Drop Syndrome Virus [25], Newcastle disease Virus [18] and Avian Influenza virus [26]. Chenicoff and Venkatachrisnan [8] reported that Aluminum-Magnesium Silicate molecules poss both positive and negative electrically charged ends. Viral genomes also have electrical charges [9]. So particles of the FPV and the other viruses so far tested may have adsorbed molecules of the AMS, by electrostatic attraction, and so, were removed from supernatants of the viral 
samples. The results suggest that AMS is an antiviral agent against Fowl Pox Virus and can be used for treatment and control of fowl pox disease.

\section{REFERENCES}

[1] Afonso, C.L., Tulman, E.R., Lu, Z., Zsak, L., Kutish, G.F. and Rock, D.L. (2000) The genome of Fowl Pox Virus. Journal of Virology, 74, 3815-3831. doi:10.1128/JVI.74.8.3815-3831.2000

[2] Adebajo, M.C., Akinyede, O. and Shittu, I.A. (2012) Seroprevalence of Fowl Pox Antibody in Indigenous Chickens in Jos North and South Council Areas of Plateau State, Nigeria: Implication for Vector Vaccine.

[3] Singh, P., Kim, T.J, and Tripathy, D.N. (2003) Identification and characterization of Fowl Pox Virus strains using monoclonal antibodies. Journal of Veterinary Diagnostic Investigation, 15, 50-54. doi:10.1177/104063870301500111

[4] Boulanger, D., Smithb, T. and Skinner M.A. (2000) Morphogenesis and release of Fowl Pox Virus. Journal of General Virology, 81, 675-687.

[5] Weli, S.C. and Tryland, M. (2011) Avipoxviruses infection biology and their use as vaccine vectors. Virology Journal, 8, 49. doi:10.1186/1743-422X-8-49

[6] Schils, S. (2002) The use of montmorillonite in the fight against harmful affects of ammonia. Journal of Renal $\mathrm{Nu}$ trition, 4, 32-36.

[7] Vanderbilt, R.T. (1992) Veegum the versatile ingredient for pharmaceutical formulation. RT Vanderbilt Co., Inc. Technical Literature, Veegum.

[8] Chernicoff, S. and Venkatakrishnan, R. (1995) Introduction to physical geology. Worth Pubications, New York.

[9] Cann, A.J. (1993) Principles of molecular biology. Academic Press, San Diego.

[10] Ezeibe, M.C.O. (2011) The synthetic aluminum-magnesium silicate. 2nd Edition. Great AP Express Pub. Ltd., Nsukka. doi:10.4236/health.2012.49102

[11] Ezeibe, M.C.O., Okoye, J.O.A., Ogunniran, T.M., Okoroafor, O.N., Ezeala, I.E. and Ngene, A.A. (2012) Modification of the passive heamagglutination test for detection of infectious bursa disease virus. Health, 4, 653-655.

[12] Ezeibe, M.C.O., Eze, J.I., Ijabo, O., Ngene, A.A., Okoroafor, O.N., Ukomadu, N.M., Sanda, E.M., Eze, I.C. and Ugonabo, J.A.C. (2010) Standardization of the PPR haemagglutinin antigen for haemagglutination-inhibition test. Journal of Applied Animal Research, 38, 113-115. doi:10.1080/09712119.2010.9707168

[13] Stern, T.B., Greenberg, M., Gershoni, J.M. and Rosenblatt, S. (1995) The haemagglutinin envelope protein of canine distemper virus confers cell tropism as illustrated by cdvmeasles virus complimentation analysis. Journal of Virology, 69, 1661-1668.

[14] Cristina, E., Ivan, P. and Kevin, R. (2007) Nanomaterials and nanoparticles: Sources and toxicity. Biointerphases, 2, MR17-MR71.

[15] Brigger, I., Dubernet, C. and Couvreur, P. (2012) Nano- particles in cancer therapy and diagnosis. Drug Delivery Review, 64, 24-36.

[16] Ezeibe, M.C.O., Mbuko, I.J., Okoroafor, O.N., Okonkwo, A.C., Animoke, P.C., Orajaka, L.J.E. and Ngene, A.A. (2009) In vitro and in vivo effects of aluminum-magnesium silicate on Infectious Bursal Disease virus in chickens. Animal Science Reports, 3, 132.

[17] Ezeibe, M.C.O., Nwaogu, I.C., Nwaigwe, A.N., Okoroafor, O.N., Eze, J.I. and Ngene, A.A. (2010) Aluminum-magnesium silicate inhibits canine parvovirus and cures infected dogs. Health, 2, 1215-1217. doi:10.4236/health.2010.210179

[18] Ezeibe, M.C.O., Okafor, U.C., Okoroafor, O.N., Eze, J.I., Ngene, A.A., Animoke, P.C. and Mbuko, I.J. (2011) Effect of aluminum-magnesium silicate on anticcocidial activity of sulphadimidine. Tropical Veterinary, 29, 41-44.

[19] Ezeibe, M.C.O., Ijabo, O., Uzopuo, C., Okoroafor, O.N., Eze, J.I., Mbuko, I.J., Sanda, M.E., Animoke, P.C. and Ngene, A.A. (2011) Effects of aluminum-magnesium silicate on newcastle disease virus and on recovery of infected chicks. International Journal of Biological and Chemical Sciences, 5, 825-829.

[20] Ezeibe, M.C.O., Elendu-Eleke, N.P., Okoroafor, O.N. and Ngene, A.A. (2012) Adjuvant effect of a synthetic aluminum-magnesium silicate on chloroquine phosphate, against plasmodium berghei. Health, 4, 448-451. doi:10.4236/health.2012.48071

[21] Ezeibe, M.C.O., Anosa, G.N., Okorie, O.K., Elendu-Eleke, N.P., Okoroafor, O.N., Ngene, A.A. and Chikelu, O.N. (2012) Aluminum-magnesium silicate enhances antibacterial activity of ampicillin trihydrate, against S. gallinarum. Health, 4, 675-678. doi:10.4236/health.2012.49106

[22] Ezeibe, M.C.O., Dire, C.D., Anosa, G.N., Chikelu, O.N., Okoroafor, O.N., Okorie, O.K., Ngene, A.A., Idika, I.K., Ogunniran, T.M. and Ezeala, I.E. (2012) Efficacy of Piperazine Citrate, stabilized with aluminum-magnesium silicate, against Helignosomoides bakeri. Health, 4, 890892. doi:10.4236/health.2012.410135

[23] Ezeibe, M.C.O., Chima, U.M., Ngene, A.A., Okoroafor, O.N., Kalu, I.I. and Esen, M.E. (2012) Effective treatment of resistant Escherichia coli infection, with sulphadimidine stabilized in a synthetic aluminum-magnesium silicate. Health, 4, 1295-1298. doi:10.4236/health.2012.412190

[24] Ezeibe, M.C.O., Ijabo, O., Okoroafor, O.N., Orajaka, L.J.E., Ukomadu, N.M., Chukwu, O.S. and Ngene, A.A. (2009) Antiviral effects of aluminum-magnesium silicate on peste des petits ruminants virus. Animal Science Reports, 3, 141-147.

[25] Ezeibe, M.C.O., Okoroafor, O.N., Ijabo, O., Ukomadu, N.M., Ngene, A.A. and Eze, J.I. (2010) Haemagglutination-inhibition and Haemagglutination titres of Egg Drop Syndrome 76 Virus treated with AMS. Animal Science Reports, 4, 87-90.

[26] Ezeibe, M.C.O., Egbuji, A.N., Eze, J.I., Ijabo, O., Ngene, A.A., Okoroafor, O.N., Eze, I.C., Ugonabo, J.A.C,. Sanda, M.E. and Mbuko, I.J. (2012) Antiviral effects of a synthetic aluminum-magnesium silicate on avian influenza virus. Health, 4, 429-432. doi:10.4236/health.2012.47067 